\title{
Meningkatkan keterampilan berpikir kritis melalui model pembelajaran decision making pada mata pelajaran Pendidikan Pancasila dan Kewarganegaraan
}

\author{
Eulis Sopia Fardiani ${ }^{a, 1}$, Yogi Nugraha ${ }^{b, 2}$, Nadya Putri Saylendra ${ }^{c, 3}$ \\ a Pendidikan Pancasila dan Kewarganegaraan, Universitas Buana Perjuangan Karawang, Indonesia \\ ${ }^{1}$ eulisfardiani@gmail.com* \\ *korespondensi penulis
}

\section{ABSTRAK}

Penelitian ini bertujuan untuk meningkatkan keterampilan berpikir kritis siswa kelas XI IPA 2 MAN 2 Karawang pada mata pelajaran PPKn melalui model pembelajaran Decision Making. Metode penelitian yang digunakan dalam penelitian ini adalah metode Penelitian Tindakan Kelas (PTK), yaitu penelitian yang dilakukan guru di dalam kelasnya sendiri dengan tujuan untuk memperbaiki kinerjanya sebagai guru, sehingga keterampilan berpikir siswa menjadi lebih meningkat. Objek penelitian ini siswa kelas XI IPA 2 MAN 2 Karawang. Jumlah siswa 34 orang dengan rincian 10 siswa laki-laki dan 24 siswa perempuan. Hasil penelitian menunjukkan bahwa penggunaan model pembelajaran Decision Making dapat meningkatkan keterampilan berpikir kritis siswa pada mata pelajaran PPKn. Dari nilai rata-rata kelas pra tindakan 28.76 dan berada pada kategori kurang, kemudian dilakukan test siklus I dan diperoleh nilai rata-rata klasikal 49.41 dan berada pada kategori cukup. Hal ini berarti terjadi peningkatan rata-rata nilai sebesar 18.12 dengan kategori peningkatan baik. Pada siklus II dan dilakukan test diperoleh nilai rata-rata klasikal 67.53 dan berada pada kategori baik dan terjadi peningkatan dari nilai rata-rata klasikal siklus I yang hanya 49.41 sebesar 18.12 dengan kategori peningkatan baik. Nilai rata-rata klasikal yang diperoleh setelah melakukan pembelajaran siklus III yaitu sebesar 91.79 dengan kategori sangat baik dan mengalami peningkatan sebesar 24.26 dari sebelumnya 18.12 pada siklus II..

\section{ABSTRACT}

This study aims to improve the critical thinking skills of students of class XI IPA 2 MAN 2 Karawang on PPKn subjects through the Decision Making learning model. The use of this learning model is one of the efforts to improve critical thinking skills of students of class XI IPA 2 MAN 2 Karawang on PPKn subjects. The research method used in this study is the Classroom Action Research (CAR) method, which is research conducted by teachers in their own class with the aim of improving their performance as teachers, so that student learning outcomes become more improved. The PTK model used is the Kemmis \& Mc model. Taggart which consists of planning, implementation, observation, and reflection. The instruments used are test results, observation, and interviews. Learning outcomes tests are used to measure students' success in critical thinking skills in the subject of analyzing cases of threats to ideology, politics, economics, socio-culture, defense and security and strategies to overcome them in the frame of Bhineka Tungga Ika). Observation and interview using observation format and interview format. The results showed that the use of the Decision Making learning model can improve students' critical thinking skills in PPKn subjects. From the pre-action class average value 28.76, it becomes 49.41 in the first cycle, 67.53 in the second cycle, and 91.79 in the third cycle..

Informasi Artikel

Diterima: 9 September 2019

Disetujui: 28 Desember 2019

Kata kunci:

Model pembelajaran Decision Making

Keterampilan berpikir kritis

\section{Article's Information}

Received: 9 September 2019

Accepted: 28 December 2019

Keywords:

Decision Making learning model Critical thinking skills

\section{Pendahuluan}

Pendidikan sebagai sarana pembangunan manusia yang memiliki karakter untuk kemajuan bangsa diharapkan terus menerus melakukan pengembangan melalui berbagai asfek baik sarana 
prasarana maupun berbagai upaya peningkatan kompetensi guru, pengembangan model pembelajaran, kurikulum, perluasan kesempatan belajar siswa, dan lain sebagainya.

Guru merupakan komponen pendidikan yang memiliki peran penting dalam pembentukan dan pengembangan siswa, sehingga diperlukan peningkatan kemampuan, kualitas dan profesionalismenya karena akan menghadapi paserta didik yang terus menerus mengikuti perkembangan ilmu dan teknologi yang berkembang pesat saat ini. Guru harus senantiasa melakukan inovasi dan kreasi dalam melakukan pembelajaran agar menarik minat siswa dalam belajar dengan senantiasa memberikan stimulus sehingga akan menumbuhkan peserta didik untuk mengembangkan kemampuan berpikir kritis dalam pembelajaran

Pada kenyataannnya pembelajaran yang dilaksaksanakan guru dilakukakan hanya sebagai rutinas untuk melaksanakan tugas sebagai pengajar, dan tidak memiliki keinginan untuk melakukan inovasi dan menghadirkan kretivias dalam kegiatan pembelajaran.

Berdasarkan hasil wawancara dengan siswa kelas XI IPA 2 MAN 2 Karawang, diketahui model pembelajaran Decision Making belum pernah dilakukan di kelas XI IPA 2. Pembelajaran di kelas lebih banyak mengggunakan metode ceramah, tanya jawab, dan diskusi kelompok. Sehingga keterampilan siswa dalam menganalisis masalah dan mengidentifikasi masalah kemudian memiliki kemampuan untuk memutuskan pemecahan masalahnya mengalami kesulitan. Keadaan di atas mendorong penulis untuk melakukan penelitian tindakan kelas dengan mengajukan model pembelajaran Decision Making pada mata pelajaran PPKn.

Bertolak dari uraian di atas maka penulis tertarik untuk meneliti dan mengetahui bagaimana meningkatkan keterampilan berpikir kritis melalui model pembelajaran Decision Making pada mata pelajaran PPKn, materi Mewaspadai Ancaman Terhadap Negara Kesatuan Republik Indonesia (KD. 3.5. Mengkaji kasus-kasus ancaman terhadap ideologi, politik, ekonomi, sosial budaya, dan pertahanan keamanan dan strategi mengatasinya dalam bingkai Bhinneka Tunggal Ika).

\section{Metode}

Metode yang digunakan dalam penelitian ini adalah Penelitian Tindakan Kelas (PTK). Penelitian Tindakan Kelas adalah suatu bentuk penyelidikan yang dilakukan melalui refleksi diri seseorang yang terlibat langsung dalam bentuk berbagai kegiatan pembelajaran dengan tujuan untuk memperbaiki proses pembelajaran. Penelitian Tindakan Kelas dilaksanakan di kelas XI IPA 2 MAN 2 Karawang. MAN 2 Karawang berlokasi di Jalan Plawad Karawang Timur. Gedung ini berdiri di atas tanah seluas 5000m2, memiliki 15 ruang kelas, 1 Laboratorium MIPA, dan 3 Laboratorium Komputer, 1 ruang perpustakaan. Metode yang digunakan dalam penelitian ini dengan melakukan observasi yang digunakan untuk mengumpulkan data tentang kemampuan berpikir kritis dan penerapan model pembelajaran Decision Making dalam pembelajaran PPKn, wawancara digunakan untuk mengumpulkan data mengenai tanggapan peserta didik tentang proses pembelajaran yang berlangsung, dan tes dipergunakan untuk mendapatkan data kemampuan berpikir kritis siswa.

\section{Hasil dan Pembahasan}

Siklus I

Pada siklus I diawali dengan test awal pra tindakan yang diperoleh hasil rata-rata klasikal sebesar 28,76 dan berada pada kategori kurang. Kemudian dilakukan test siklus I dan diperoleh nilai rata-rata klasikal 49.41 dan berada pada kategori cukup. Hal ini berarti terjadi peningkatan rata-rata nilai sebesar 18.12 dengan kategori peningkatan baik. Hasil data non test pada siklus I Sebagian besar siswa belum terlihat aktif dan inisiatif untuk menyampaikan hasil analisisnya terhadap pokok bahasan menganalisis kasus-kasus ancaman terhadap ideologi, politik, ekonomi, sosial budaya, dan 
pertahanan keamanan dan strategi mengatasinya dalam bingkai Bhineka Tunggal Ika, atau memberikan tanggapan dalam proses pembelajaran menggunakan Model Pembelajaran Descision Making ,

Siklus II

Pada siklus II dan dilakukan test diperoleh nilai rata-rata klasikal 67.53 dan berada pada kategori baik dan terjadi peningkatan dari nilai rata-rata klasikal siklus I yang hanya 49.41 sebesar 18.12 dengan kategori peningkatan baik. Hasil data non test siklus II menunjukkan pembelajaran siklus II membuat siswa lebih memahami dan lebih tertarik dengan pembelajaran yang menggunakan Model Pembelajaran Descision Making

Siklus III

Nilai rata-rata klasikal yang diperoleh setelah melakukan pembelajaran siklus III yaitu sebesar 91.79 dengan kategori sangat baik dan mengalami peningkatan sebesar 24.26 dari sebelumnya 18.12 pada siklus II. Pembelajaran pada siklus III ini bertujuan untuk lebih meningkatkan keterampilan berpikir kritis. Hasil data non test siklus III menunjukkan peningkatan yang stabil dari siklus-siklus sebelumnya. Keseluruhan aspek yang dinilai mengalami peningkatan yang baik, hal ini dikarenakan perilaku siswa yang semakin baik dan sudah mampu memahami pembelajaran yang menggunakan Model Pembelajaran Descision Making sehingga suasana belajar pun terasa lebih aktif dan siswa memahami materi yang diberikan

\section{Simpulan}

Kesimpulan yaitu 1) penggunaan Model Pembelajaran Descision Making Dalam Meningkatkan keterampilan berpikir kritis Siswa Pada Mata Pelajaran Pendidikan Pancasila dan Kewarganegaraan (Penelitian Tindakan Kelas Pada Siswa Kelas XI IPA 2 MAN 2 Karawang) pada siklus I diawali dengan test awal pra tindakan yang diperoleh hasil rata-rata klasikal sebesar 28,76 dan berada pada kategori kurang. Kemudian dilakukan test siklus I dan diperoleh nilai rata-rata klasikal 49.41 dan berada pada kategori cukup. Hal ini berarti terjadi peningkatan rata-rata nilai sebesar 18.12 dengan kategori peningkatan baik; 2) hasil data non test pada siklus I menunjukkan bahwa sebagian siswa kurang memahami materi dan nampak masih bingung memulai pembelajaran, sehingga pembelajaran tidak berjalan baik dalam mengikuti pembelajaran menggunakan Model Pembelajaran Descision Making. Keterlibatan siswa dalam mengikuti diskusi kelompok belum terlihat, masing-masing individu bekerja secara individu sehingga suasana belajar kelompok kurang aktif. Hasil observasi yang diperoleh peneliti menunjukkan bahwa ketika kelompok belajar melakukan pembahasan secara berkelompok terlihat ada keinginan untuk ikut serta dalam pembelajaran sehingga sebesar $88.23 \%$ siswa tertarik terhadap Model Pembelajaran Descision Making yang diterapkan, dan sebagian siswa lainnya masih terlihat biasa-biasa saja. Pada saat mengerjakan test individu sebagian besar siswa mengerjakan secara individu walaupun masih ada beberapa siswa yang mencoba bertanya kepada temannya. Berdasarkan hasil data test dan non test tersebut, peneliti merasa masih perlu melaksanakan pembelajaran siklus II; 3) Setelah dilakukan pembelajaran pada siklus II dan dilakukan test diperoleh nilai rata-rata klasikal 67.53 dan berada pada kategori baik dan terjadi peningkatan dari nilai rata-rata klasikal siklus I yang hanya 49.41 sebesar 18.12 dengan kategori peningkatan baik; 4) hasil data non test siklus II menunjukkan bahwa siswa kelas XI IPA 2 MAN 2 Karawang telah mengalami peningkatan dalam proses pembelajaran. Hal ini ditandai dengan kesungguhan siswa XI IPA 2 dalam mengikuti langkah-langkah Model Pembelajaran Descision Making pembelajaran menjadi lebih hidup dikarenakan siswa aktif dalam pembelajaran. Kemampuan untuk mengajukan pertanyaan, menyampaikan gagasan dalam proses pembelajaran telah nampak. Pembelajaran siklus II membuat siswa lebih memahami dan lebih tertarik dengan pembelajaran yang menggunakan Model 
Pembelajaran Descision Making; 5) Nilai rata-rata klasikal yang diperoleh setelah melakukan pembelajaran siklus III yaitu sebesar 91.79 dengan kategori sangat baik dan mengalami peningkatan sebesar 24.26 dari sebelumnya 18.12 pada siklus II. Pembelajaran pada siklus III ini bertujuan untuk lebih meningkatkan keterampilan berpikir kritis; dan 6) Hasil data non test siklus III menunjukkan peningkatan yang stabil dari siklus-siklus sebelumnya. Keseluruhan aspek yang dinilai mengalami peningkatan yang baik, hal ini dikarenakan perilaku siswa yang semakin baik dan sudah mampu memahami pembelajaran yang menggunakan Model Pembelajaran Descision Making sehingga suasana belajar pun terasa lebih aktif dan siswa memahami materi yang diberikan

\section{Referensi}

Crick, B. (2002). Dharma dan Siregar. (2014). Internalisasi Karakter melalui Model Project Citizen pada Pembelajaran Pendidikan Pancasila dan Kewarganegaraan. Jurnal Pendidikan IImu-IImu Sosial, 6, (2,) 133-134.

Ikman, dkk. (2016) Effect of Problem Based Learning (pbl) Models of Critical Thinking Ability Students on the Early Mathematics Ability. International Journal of Education and Research, 4 (7), 4-5.

Murdiono, Muhakhamad. (2008) Peningkatan Keterampilan Kewarganegaraan (Civic Skill) Melalui Penerapan Strategi Pembelajaran Berbasisi Masalah (Problem Based Learning). Jurnal Penelitian Pendidikan, 6-7.

Septiyan. (2017). Pengaruh Model Teams Game Tournament Terhadap Keterampilan Pengambilan keputusan dalam Pembelajaran IPS di Sekolah dasar. Jurnal. Mimbar Sekolah Dasar,4, (1), 109-110.

Winarso,Widodo. (2014) Problem Solving, Creativity dan Decision Making Dalam Pembelajaran Matematika. EduMa, 3 (1), 12-14.

Skripsi : Nurhasanah. 2014. Penerapan Model Pembelajaran Kooperatif Tipe Decison Making Untuk Meningkatkan Hasil Belajar Siswa Pada Mata Pelajaran Ilmu Pengetahuan Sosial Kelas IV D Sekolah Dasar Negeri 42 Kecamatan Marpoyan Damai Pekanbaru. Skripsi thesis. Univesitas Islam Negeri Sutan Syarif Kasim Riau. Dalam situs http://repository.uin-suska.ac.id/5382/ dikases pada tanggal 06 Februari, pukul 15.01 Wib.]Democracy: A very short introduction. Oxford University Press Inc. https://doi.org/10.1007/s13398-014-0173-7.2

Flanagan, C., Levine, P., \& Settersten, R. (2007). Civic engagement and the transition to adulthood. CIRCLE.

Hobbs, R. (2010). Digital and media literacy. A plan of action. In Journal of Craniofacial Surgery (Vol. 23, Nomor 5). The Aspen Institute Communications and Society Program One. https://doi.org/10.1097/SCS.0b013e31824e27c7

Michels, A., \& De Graaf, L. (2017). Examining citizen participation: Local participatory policymaking and democracy revisited. Local Government Studies, 43(6), 875-881.

https://doi.org/10.1080/03003930.2017.1365712 